\title{
First record of Late Miocene Dendrophyllia de Blainville, 1830 (Scleractinia: Dendrophylliidae) in Taiwan
}

\author{
Lauriane Ribas-Deulofeu ${ }^{1,2}$, Yen-Chun Wang ${ }^{1}$, Chien-Hsiang Lin ${ }^{1, *}$ \\ ${ }^{1}$ Biodiversity Research Center, Academia Sinica, Taipei City, Taiwan \\ ${ }^{2}$ Institute of Oceanography, National Taiwan University, Taipei City, Taiwan
}

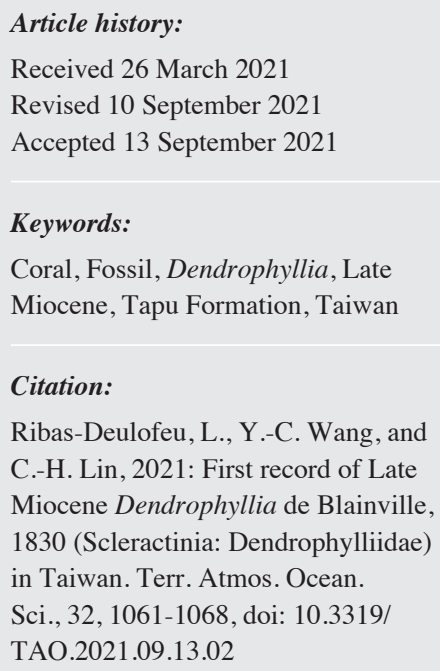

Citation:

Ribas-Deulofeu, L., Y.-C. Wang, and C.-H. Lin, 2021: First record of Late Miocene Dendrophyllia de Blainville, 1830 (Scleractinia: Dendrophylliidae) in Taiwan. Terr. Atmos. Ocean. Sci., 32, 1061-1068, doi: 10.3319/ TAO.2021.09.13.02

\begin{abstract}
The recently exposed outcrops along the Dahan River in Shulin, northern Taiwan revealed diverse and abundant marine fossils including molluscs, shark and ray teeth, sand dollars, and otoliths from a wide range of fish taxa. In addition, numerous small and fragile fossil scleractinians were found and identified here as Dendrophyllia sp., from the mainly azooxanthellate (90\%) dendrophylliid family. Lithology of the outcrops are mainly composed of grey sandstones from the Tapu Formation (Late Miocene), overlying on a layer of basaltic tuff. The absolute age of the boundary between the Tapu Formation and the underlying Nanchuang Formation is $8 \mathrm{Ma}$, which provides indications on the maximum age possible for the scleractinian fossils found in this study. Back then, the marine ecosystem in which the sampled Dendropyllia specimens grew was probably a turbid shallow coastal environment with muddy to sandy bottom, likely at the vicinity of a river estuary, as suggested by the combined presence of previously reported fish otoliths. To our knowledge, this is the first record of Dendrophyllia fossils from Taiwan.
\end{abstract}

\section{INTRODUCTION}

Over the last decades, coral reefs have been impacted by significant degradations from the ongoing anthropogenically-caused climate change and the increasing local human pressures that jeopardize the ability of coral reefs to persist in the near future (Hughes et al. 2017). These predictions are contrasted by the fact that coral reef ecosystems have existed for more than 500 million years (Riegl et al. 2009). The appearance of modern coral (Scleractinia) can be traced back to at least the Permo-Triassic mass-extinction event (251 Ma) when they gradually became the major contributors to reef accretion (Pandolfi 2011). Since then, scleractinian corals have survived two additional mass-extinction events (the Triassic-Jurassic event at $200 \mathrm{Ma}$ and the Cretaceous-Paleogene event at $66 \mathrm{Ma}$ ), which were triggered by cataclysms (massive volcanic activities for the TriassicJurassic and the Cretaceous-Paleogene events; and an asteroid impact for the Cretaceous-Paleogene event) that drove

\footnotetext{
* Corresponding author

E-mail: chlin.otolith@gmail.com
}

atmospheric $\mathrm{CO}_{2}$ levels above 3000 ppmv (Retallack 2002). Current studies have suggested that our planet, and especially coral reef ecosystems are currently in the midst of another mass-extinction event, driven by the intensive anthropogenic pressures at planetary scale (Pandolfi et al. 2011).

The fossil reefs, and the calcified remains within, are unique witnesses of the past, holding critical physical, biological and chemical information (Hubbard 2011). Studying these remains, in particular coral fossils, allows scientists to reconstruct the functioning of the coral ecosystems prior to any anthropogenic exploitation or under different climatic contexts that are nowadays no longer observable (Pandolfi 2011). Paleoecological studies can further unveil the geological legacies on reefs' resilience abilities through their respective long-term evolutionary trajectory that led to the more or less diverse local scleractinian coral communities (Huang et al. 2015). These past pieces of knowledge are critically needed by the scientific community in order to adequately preserve reef functioning and ultimately ensure the survival of this essential ecosystem (Cybulski et al. 2020). 
Taiwanese coral reefs and non-reefal coral communities are among the most diverse marine ecosystems on earth, hosting over a third of the world scleractinian diversity (558 species, Dai and Cheng 2020) and over 1400 reef fish species (Denis et al. 2019a). The extraordinary biodiversity hosted by Taiwanese reefs, along with the coastal protection and recreational activities offered by this ecosystem, constitute a critical economic resource to the Taiwanese economy, with an average value of $514.417 \mathrm{US} \$ / \mathrm{km}^{2} /$ year (Spalding et al. 2017). However, the multiple anthropogenic pressures along with the highly active typhoon regime and recurrent heat stress anomalies have induced major degradations of the Taiwanese reefs (Kuo et al. 2012; Ribas-Deulofeu et al. 2016, 2021; Denis et al. 2019b; Keshavmurthy et al. 2019), making them one of the five most threatened reef regions in South-East Asia (Burke et al. 2002). While modern Taiwanese reef biota have been relatively well characterized, little is known of their past long-term evolutionary trajectory which led to the diversification of its highly diverse scleractinian coral communities (Huang et al. 2015). In the 1980-90s, research papers have reported free-living coral fossils from the Plio-Pleistocene deposits in Miaoli, Tainan and Hengchung Peninsula along with a few Cyphastrea sp., Coscinera exesa, and dendrophyllid fossils (Balanophyllia oulangiformis, Heteropsammia ovalis and michelini and, Leptopsammia formosa previously reported as a Balanophyllia) (Hu and Tao 1982; Hu 1987a, b, 1988, 1990). In addition, Pleistocene coral fossils have been found in Takangshan area, near Kaoshiung City (Wang et al. 2006). In this study, a wide variety of scleractinian fossils was reported, including free-living corals such as Cycloseris, Fungia, Heliofungia, and Herpolitha (Wang et al. 2006). The fossil scleractinian community in the study of Wang et al. (2006) was also composed of specimens of Acropora, Acanthastrea, Cyphastrea, Dipsastreae, Favites, Goniopora, Goniastrea, Galaxea, Pachyseris, Porites, and Turbinaria, which was the only representative of the dendrophylliids (Wang et al. 2006). More diverse scleractinian communities have been reported from uplifted Holocene terraces in Ludao and Lanyu (Inoue et al. 2011; Ota et al. 2015; Shen et al. 2018). The fossil specimens presented in our study constitutes the first report of Late Miocene scleractinian fossils from Shulin area, northern Taiwan, which hold environmental and ecological information that inform us on the formation of the Taiwanese scleractinian community at a much earlier time than the previous studies in the country on the scleractinian fossils (Hu and Tao 1982; Hu 1987a, b, 1988, 1990; Wang 1997; Yamaguchi and Ota 2004; Wang et al. 2006; Inoue et al. 2011; Ota et al. 2015; Shen et al. 2018).

\section{MATERIALS AND METHODS}

\subsection{Study Area and Geological Setting}

Fossil specimens were sampled in two sites, SL-3 and
SL-4 (Fig. 1, Supplementary Fig. S1), along the Dahan River in Shulin District, New Taipei City (Fig. 1). In the sampling area, the boundary between the Nanchuang Formation and overlying Tapu Formation are exposed (Lin et al. 2021), and the fossils were collected from the lowest part of the Late Miocene Tapu Formation (Fig. 2). In the outcrop, a notable basaltic tuff layer of approximately two meters can be observed. The absolute age of the boundary between the Tapu Formation and the underlying Nanchuang Formation is $8 \mathrm{Ma}$ (Tsao et al. 1992), which provide indications on the maximum age possible for the scleractinian fossils found in this study. The difference in the

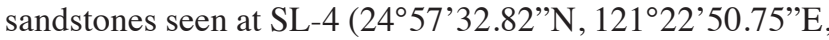
Fig. 1c) and SL-3 $\left(24^{\circ} 57^{\prime} 40.25^{\prime \prime} \mathrm{N}, 121^{\circ} 23^{\prime} 05.18^{\prime \prime} \mathrm{E}\right)$ is that the one observed in SL-3 is disrupted by a layer of matrixsupported tuff conglomerates about $40 \mathrm{~cm}$ thick (Fig. 1d). The bed attitude of those exposed sandstone strata at both sites have a strike of $\mathrm{N} 50^{\circ} \mathrm{E}$ and a dip of $80^{\circ}$ toward the west. According to sedimentological studies (Ho 1986; Hong and Wang 1988), the Tapu Formation is composed of inshore deposits.

\subsection{Sampling}

Fossils from Shulin area were first reported in 2010 (Lin 2010) but the site reported therein was flushed away in the rainy seasons between 2015 to 2016 . Our coral specimens, sampled from new outcrops at sites SL-3 and SL-4 (Figs. 1 and 2, Supplementary Fig. S1), can be frequently observed on the surface of the strata (Lin et al. 2021; Lin and Chien 2022). However, fragility of coral specimens required delicate sampling using hammer and chisel. Specimens were then cleaned using water and a toothbrush to remove the sediments.

\section{RESULTS}

During the investigations of the Shulin sites, diverse and abundant marine remains have been found, including molluscs, shark and ray teeth, sand dollars, and $>1700$ otoliths (from $>30$ otolith-based taxa) (Lin and Chien 2022). In addition, numerous small fragments of scleractinians were found (Fig. 3). However, all these fragments likely belong to a single species of the genus Dendrophyllia. Fewer specimens $(<20)$ were found in SL-3 than in SL-4 and most of them could not be extracted from their surrounding sediment material without breaking the specimens. Dendrophyllia specimens in SL-4 were easily found and relatively abundant but extremely fragile, likely due to subaerial weathering and rainwater leaching (Lin and Chien 2022). The collected specimens in SL-4 rarely exceeded $5 \mathrm{~cm}$ in size and were mostly found as 1 to $2 \mathrm{~cm}$ fragments (Fig. 3). Many were broken during extraction and simple ultrasonic washing was sufficient to break them further. 

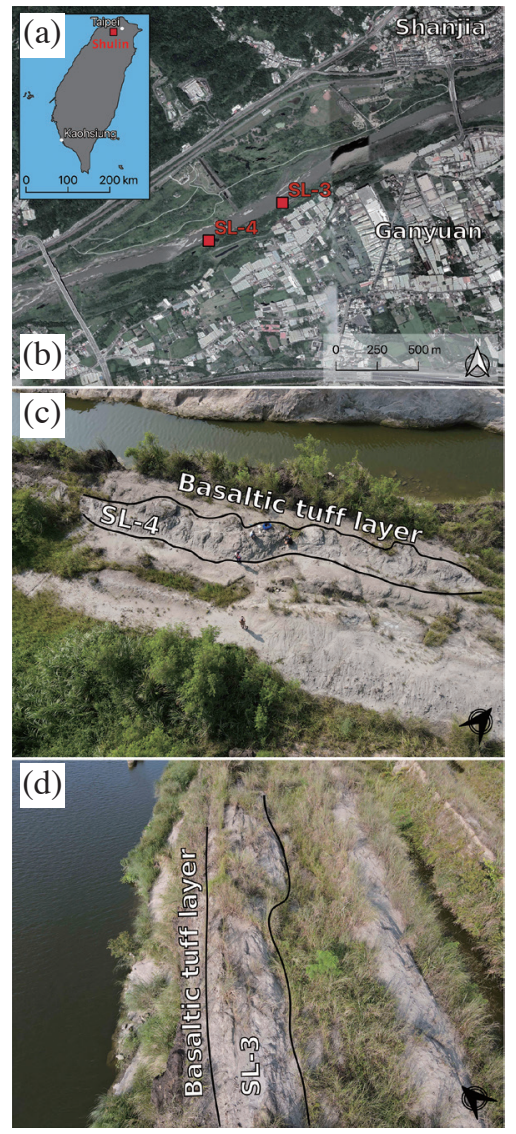

Fig. 1. Study sites. (a) Location of Shulin District, New Taipei City. (b) Sampled sites SL-3 and SL-4 along the Dahan River, in Shulin area. (c) Aerial view of SL-4 and, (d) Aerial view of SL-3.

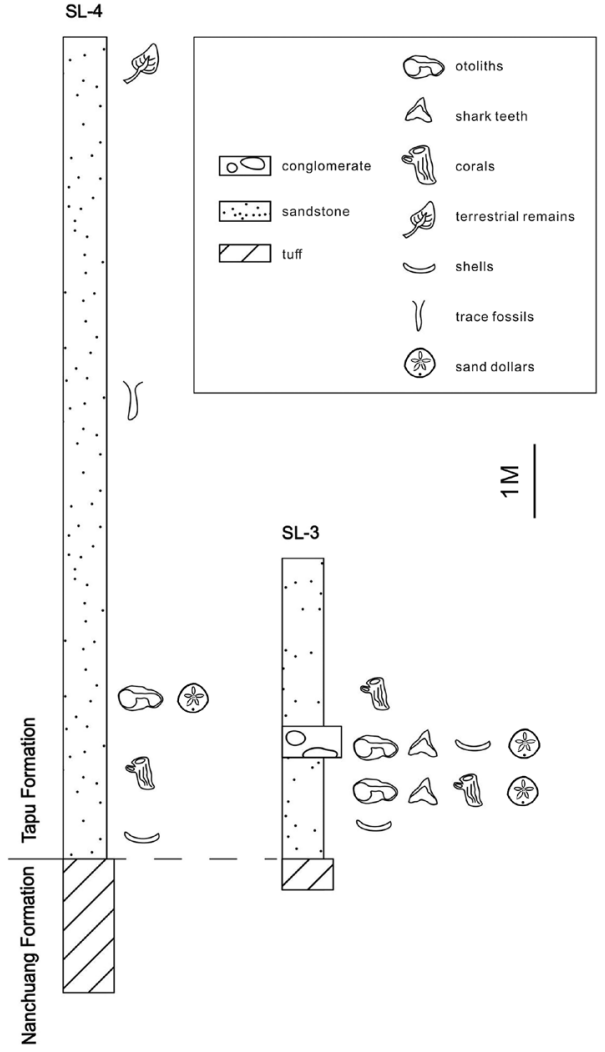

Fig. 2. Stratigraphic columns of the studied sites (modified after Lin and Chien 2022)

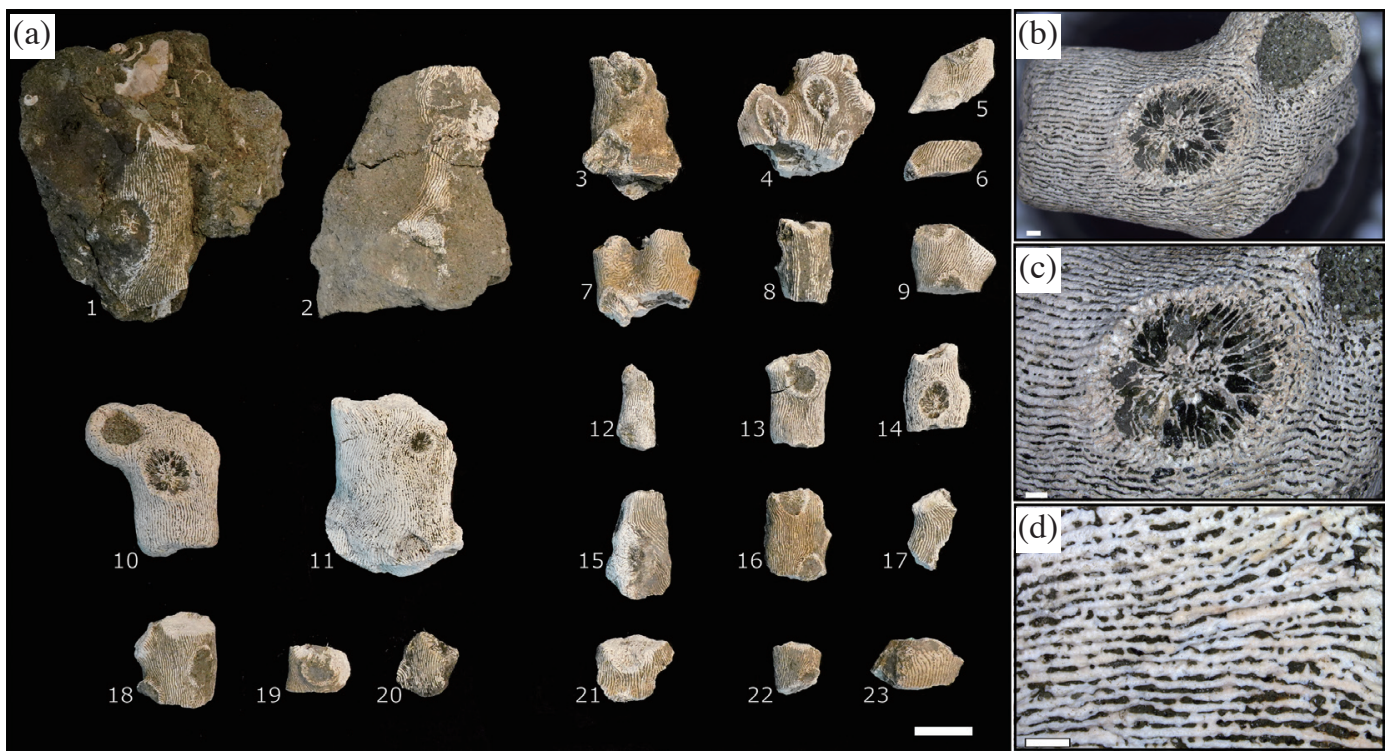

Fig. 3.Dendrophyllia sp. fossils from SL-4. (a) General view of 23 fossil specimens deposited at the Biodiversity Research Museum, Academia Sinica, Taiwan (BRMAS, http://museum.biodiv.tw/eng). (Museum references: 1. ASIZF0100142, 2. ASIZF0100148, 3. ASIZF0100149, 4. ASIZF0100150, 5. ASIZF0100151, 6. ASIZF0100159, 7. ASIZF0100152, 8. ASIZF0100153, 9. ASIZF0100154, 10. ASIZF0100143, 11. ASIZF0100144, 12. ASIZF0100145, 13. ASIZF0100146, 14. ASIZF0100147, 15. ASIZF0100155, 16. ASIZF0100157, 17. ASIZF0100158, 18. ASIZF0100156, 19. ASIZF0100160, 20. ASIZF0100161, 21. ASIZF0100162, 22. ASIZF0100163, 23. ASIZF0100164) (b) Close-up view of specimen ASIZF0100143. (c) Close-up view of the corallite of specimen ASIZF0100143, showing a Pourtalès arrangement of the septa. (d) Close-up view of the costae of specimen ASIZF0100144. Scale bar in figure (a) is $1 \mathrm{~cm}$ while in (b), (c), and (d), the scale bars represent $1 \mathrm{~mm}$. 


\subsection{Systematic Paleontology}

Class: Anthozoa Ehrenberg, 1834

Order: Scleractinia Bourne, 1900

Suborder: Dendrophylliina Vaughan and Wells, 1943

Family: Dendrophylliidae Gray, 1847

Genus: Dendrophyllia de Blainville, 1830

Type species: Dendrophyllia ramea (Linnaeus, 1758)

Diversity: A total of 85 species of Dendrophyllia were listed by Cairns (2001), including 29 valid extant species and 56 extinct species, among which two nomina nuda species (one extant and one extinct species). The oldest Dendrophyllia was reported from the Campanian-Maastrichtian (Late Cretaceous) of Tibet (Löser and Liao 2001).

Specimen description: Dendroid colonies. Septa display a four-cycle arrangement and are organized in Pourtalès plan (Fig. 3). Columella is porous with a circular or elliptical shape (Fig. 3). Budding is extratentacular. The costae are well-defined with deep interstices presenting irregular connections between costae (Fig. 3, Supplementary File S1). Despite superficial erosion of the costae, they occasionally seem to display granular or even hispid aspects (Fig. 3). From the specimens on which corallites and/or branch diameters were measurables, 20 specimens were randomly picked for measurements. Mean corallites diameter is $6.15 \pm 1.38 \mathrm{~mm}$, with a minimum of $4.58 \mathrm{~mm}$ and a maximum of $8.87 \mathrm{~mm}$, while mean branch diameter is $9.77 \pm 4.43 \mathrm{~mm}$ with branch diameters ranging from 4.39 to $21.54 \mathrm{~mm}$.

Remarks: Dendrophyllia colonies originate from a single basal stem and have been organized into three groups by Cairns (2001):

- Group 1: arborescent colonies with axial corallites (e.g., D. ramea, D. cribosa),

- Group 2: small, bushy colonies with sparse branches from the main stem (e.g., D. carleenae, D. cornigera),

- Group 3: dendroid colonies with sympodial branching (e.g., D. minima, D. oldroydae).

Specimens presented in this study belong to the Group 2, but due to the preservation condition, we are not able to identify them to species level.

Structure from Motion (SfM) 3D model of the specimen ASIZF0100147 is provided in the supplementary materials (Supplementary File S1).

Locality and Horizon: Shulin, basal Tapu Formation Museum access numbers: Biodiversity Research Museum, Academia Sinica, Taiwan (BRMAS, http://museum.biodiv. tw/eng), Specimens ASIZF0100142 to ASIZF0100164.

\section{DISCUSSION}

\subsection{Taxonomy and Ecology of Modern Dendrophyllia}

Collected specimens in SL-3 and SL-4 have been identified as a Cairns' Group 2 type of Dendrophyllia sp. (Fig. 3,
Supplementary File S1). Dendrophylliids are at 90\% azooxanthellate ( 149 out of 166 modern species, Cairns 2001), which has allowed them to colonize a wide geographic and bathymetric range, including cryptic locations or caves. Indeed, in the $21^{\text {st }}$ century, living colonies of modern dendrophylliids are found from the North Sea to the sub-Antarctic region, at depths ranging from 0 to $2165 \mathrm{~m}$ (Cairns 2001). Dendrophyllia are among the azooxanthellate genera of the dendrophylliids and colonize seafloors up to $900 \mathrm{~m}$ in depth (Hoeksema and Cairns 2021). To date, 85 species of Dendrophyllia have been described, including 56 extinct species (Cairns 2001). An additional 72 species names have been identified as either synonymy or former Dendrophyllia species that have now been renamed and attributed to other dendrophylliids, mainly Tubastraea, Eguchipsammia, and Enallopsammia (Hoeksema and Cairns 2021).

In Taiwan, modern scleractinian diversity (558 species) accounts for two species of Dendrophyllia [D. alcocki (Wells 1954) and D. arbuscula (Van der Horst 1922)] along with 29 other species of dendrophylliids from the genera Balanophyllia (8 species), Turbinaria (7 species), Tubastraea (6 species), Eguchipsammia (4 species.), Cladopsammia (1 species), Enallopsammia (1 species), Endopachys (1 species), and Heteropsammia (1 species) (Dai and Cheng 2020). D. arbuscula (Van der Horst 1922) has been reported on hard substrates in Taiwan at depths from 45 to $240 \mathrm{~m}$, while D. alcocki (Wells 1954) are found from 118 to $570 \mathrm{~m}$ (Dai and Cheng 2020). In addition, an early underwater survey of the marine biological diversity of the Southern Taiwan (Kenting) has reported three unidentified species of Dendrophilla, observed as dominant coral species along $T u$ bastrea aurea in shallower depths (5 to $20 \mathrm{~m}$ ) where walls, blocks and boulders created habitats with reduced light (Jones et al. 1972).

\subsection{Field Taphonomy Observations}

Although the Dendrophyllia skeletons retrieved no longer present the rough sandy aspect that characterize them, these fossil corals are considered well preserved (Fig. 3). Based on field observations, the bioclasts in sandstones were deposited as matrix-supported, and no firm substrate for Dendrophyllia growth was found in the sandstone at the two locations (Figs. 1c, d, and Supplementary Fig. S1). Therefore, these sandstone strata and tuff conglomerate appear to be mass-transported deposits, and the fossil corals may not be buried in situ but reflecting a concentration of geological events.

\subsection{Paleo-Ecological Implications from Fossil Assemblages}

The marine ecosystem that constituted SL-3 and SL-4 
were probably not as deep as we could have expected it to be from the presence of Dendrophyllia spp. (depths ranging from $\sim 40$ to $600 \mathrm{~m}$ for extant species) but was a turbid shallow coastal environment with muddy to sandy bottom, likely at the vicinity of a river estuary. Indeed, coastal marine ecosystems at the proximity of river mouths usually present turbid conditions, which would be consistent with the presence of azooxanthellate corals such as Dendrophyllia sp.; as turbidity reduces the light penetration in the water column. This is reinforced by the sedimentary environment of the Tapu Formation as well as by the presence of sand dollars but most of all, by the numerous Ariidae and Sciaenidae otoliths retrieved in these sites by Lin and Chien (2022).

\subsection{Fossil Records of Dendrophyllia}

To date, the oldest dendrophylliid geological record can be dated back to the Late Pliensbachian (Early Jurassic), from Slovenia (Turnšek et al. 2003). Whilst, the oldest Dendrophyllia record is from the Campanian-Maastrichtian (Late Cretaceous), from the Tibetan region by Löser and Liao (2001). Fossil specimens of Dendrophyllia have been found from a wide range both in time and space (Table 1). Combining data from Cairns (2001), the Paleobiological Database (https://www.paleobiodb.org/classic) and our knowledge, specimens from this study are the first fossil Dendrophyllia recorded from Taiwan.

Table 1. Locations and geological epochs of recorded fossils of Dendrophyllia spp.: (a) in Cairns (2001) and (b) on the Paleobiology database (https://www.paleobiodb.org/classic). The * represents fossils recorded in the present study.

\begin{tabular}{|c|c|c|c|c|c|c|c|c|}
\hline & & \multirow{2}{*}{$\begin{array}{c}\text { Cretaceous } \\
\text { Late Cretaceous }\end{array}$} & \multicolumn{3}{|c|}{ Paleogene } & \multicolumn{2}{|c|}{ Neogene } & \multirow{2}{*}{$\begin{array}{r}\text { Quaternary } \\
\text { Pleistocene }\end{array}$} \\
\hline & & & Paleocene & Eocene & Oligocene & Miocene & Pliocene & \\
\hline Asia & $\begin{array}{l}\text { China } \\
\text { Japan } \\
\text { Taiwan }\end{array}$ & $\mathrm{b}$ & & & & $\begin{array}{c}\mathrm{a}, \mathrm{b} \\
*\end{array}$ & & a \\
\hline South-East Asia & $\begin{array}{c}\text { Borneo } \\
\text { Indonesia } \\
\text { Java } \\
\text { Myanmar }\end{array}$ & & & & $\mathrm{b}$ & $\begin{array}{l}\mathrm{a} \\
\mathrm{a}\end{array}$ & $\begin{array}{l}\mathrm{a} \\
\mathrm{b} \\
\mathrm{a}\end{array}$ & $\mathrm{b}$ \\
\hline South Pacific & $\begin{array}{c}\text { Australia } \\
\text { New Zealand } \\
\text { Tasmania } \\
\text { Vanuatu }\end{array}$ & & $\mathrm{b}$ & $\mathrm{a}, \mathrm{b}$ & & $\begin{array}{l}\mathrm{b} \\
\mathrm{b} \\
\mathrm{a}\end{array}$ & & $\mathrm{a}, \mathrm{b}$ \\
\hline USA & $\begin{array}{c}\text { Alabama } \\
\text { California } \\
\text { Louisiana } \\
\text { Mississippi } \\
\text { South Carolina } \\
\text { Washington }\end{array}$ & & $\mathrm{b}$ & $\begin{array}{l}a, b \\
a, b \\
a, b \\
b \\
a \\
a, b\end{array}$ & $\mathrm{~b}$ & & $\mathrm{a}, \mathrm{b}$ & \\
\hline Caribbean & $\begin{array}{c}\text { Dominican Republic } \\
\text { Grenada } \\
\text { Jamaica } \\
\end{array}$ & $\mathrm{b}$ & & & & $\begin{array}{l}\mathrm{b} \\
\mathrm{b}\end{array}$ & $\mathrm{b}$ & \\
\hline South America & $\begin{array}{c}\text { Brazil } \\
\text { Peru } \\
\text { Venezuela }\end{array}$ & & & $\mathrm{a}, \mathrm{b}$ & $\mathrm{a}, \mathrm{b}$ & $\begin{array}{l}\mathrm{b} \\
\mathrm{b}\end{array}$ & & \\
\hline Europe & $\begin{array}{c}\text { Austria } \\
\text { Crete } \\
\text { Czech Republic } \\
\text { Czechoslovakia (Former) } \\
\text { Denmark } \\
\text { England }\end{array}$ & & $\mathrm{a}, \mathrm{b}$ & $\mathrm{a}$ & a & $\begin{array}{l}\mathrm{a} \\
\mathrm{b} \\
\mathrm{a}\end{array}$ & & \\
\hline
\end{tabular}


Table 1. (Continued)

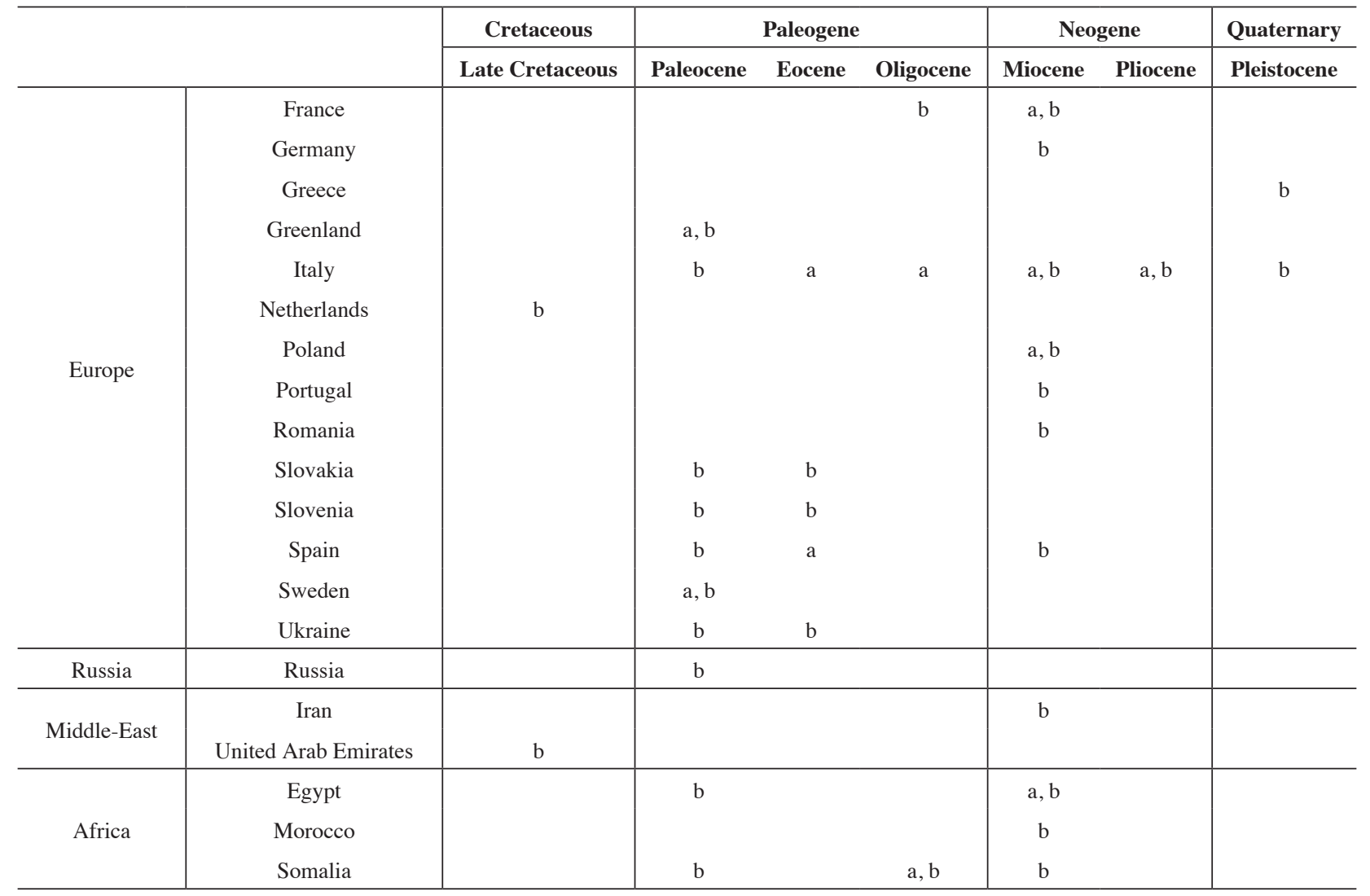

Acknowledgements We would like to thank Prof. ChangFeng Dai for his advice and comments on the coral taxonomy and Dr. Yoko Nozawa for teaching us SfM 3D model techniques and lending us his equipment. Lauriane RibasDeulofeu would like to thank Éadaoin Close and Eva Wolzok for their English editing and their support. We thank all the people who took us to the sites and helped in the field: Chao-Ping Jiang, Ching-Tung Hsiung, Ching-Yuan Lee, Chia-Fong Chen, Shih-Chuan Chen, Chih-Kai Chuang, Shih-Wei Lee (National Museum of Marine Science and Technology, Keelung, Taiwan), Meng-Chen Ko, Li-You Lin and the members of Marine Paleontology Lab, BRCAS (https://otolithlin.biodiv.tw/). Funding was provided by the Ministry of Science and Technology, Taiwan (Grant No. 108-2116-M-029-001-MY2, 109-2116-M-001-022-, 1102116-M-001-009-) and Academia Sinica, Taipei, Taiwan to Chien-Hsiang Lin.

\section{REFERENCES}

Burke, L., E. Selig, and M. Spalding, 2002: Reefs at Risk in Southeast Asia, Cambridge, 72 pp.

Cairns, S. D., 2001: A generic revision and phylogenetic analysis of the Dendrophylliidae (Cnidaria: Scleractinia). Smithsonian Contributions to Zoology, 615, 1-75, doi: 10.5479/si.00810282.615. [Link]

Cybulski, J. D., S. M. Husa, N. N. Duprey, B. L. Mamo, T. P. N. Tsang, M. Yasuhara, J. Y. Xie, J.-W. Qiu, Y. Yokoyama, and D. M. Baker, 2020: Coral Reef Diversity Losses in China's Greater Bay Area Were Driven by Regional Stressors. Sci. Adv., 6, eabb1046, doi: 10.1126/sciadv.abb1046. [Link]

Dai, C.-F. and Y.-R. Cheng, 2020: Corals of Taiwan. Vol.1: Scleractinia Fauna, Owl Publishing House Co., LTD., 560 pp. (in Chinese)

Denis, V., J.-W. Chen, Q. Chen, Y. E. Hsieh, Y. V. Lin, C.W. Wang, H.-Y. Wang, and N. Sturaro, 2019a: Biogeography of functional trait diversity in the Taiwanese reef fish fauna. Ecol. Evol., 9, 522-532, doi: 10.1002/ ece3.4771. [Link]

Denis, V., D. Soto, S. De Palmas, Y. T. V. Lin, Y. Benayahu, Y. M. Huang, S.-L. Liu, J.-W. Chen, Q. Chen, N. Sturaro, M.-J. Ho, Y. Su, C. F. Dai, and C. A. Chen, 2019b: Taiwan. In: Loya, Y., K. A. Puglise, and T. C. L. Bridge (Eds.), Mesophotic Coral Ecosystems, Springer, Cham, 249-264, doi: 10.1007/978-3-31992735-0_14. [Link]

Ho, C.-S., 1986: An Introduction to the Geology of Taiwan, Central Geological Survey, The Ministry of Economic Affairs Press, 192 pp. (in Chinese) 
Hoeksema, B. W. and S. D. Cairns, 2021: Word list of Scleractinia - Dendrophyllia de Blainville, 1830. Available at http://www.marinespecies.org/scleractinia/aphia.php? $\mathrm{p}=$ taxdetails\&id=135110. [Accessed 16 March 2021]

Hong, E. and Y. Wang, 1988: Basin analysis of the Upper Miocene - Lower Pliocene Series in Northwestern Taiwan. Ti-Chih, 8, 1-20. (in Chinese)

Hu, C.-H., 1987a: Manual for ten geological routes in northern Taiwan - route 5: Geology of Baishatun, Miaoli. In: National Taiwan Normal University Faculty Members of the Department of Earth Sciences (Taipei) (Ed.), Field Manual of the Geology of Taiwan (I), 63100. (in Chinese)

Hu, C.-H., 1987b: Unusual fossil corals from Hengchun Peninsula, Southern Taiwan. Mem. Geol. Soc. China, 8, 31-48.

Hu, C.-H., 1988: Some solitary fossil corals and paleoecology of the Tunghsiao and Lungkang formations of Miaoli Region, Northern Taiwan. Proc. Geol. Soc. China, 31, 140-153.

Hu, C.-H., 1990: Manual for ten geological routes in northern Taiwan-route 1: Geology of Hengchun Penninsula, Southernmost part of Taiwan (Hengchun-Eluanbi-Longpan). In: National Taiwan Normal University Faculty members of the Department of Earth Sciences (Taipei) (Ed.), Field manual of the geology of Taiwan (I), 5-71. (in Chinese)

Hu, C.-H. and H.-J. Tao, 1982: A new species of solitary corals and associated fossils from the lower Gutingkeng formation of Taiwan. Ti-Chih, 4, 39-46. (in Chinese)

Huang, D., W. Y. Licuanan, B. W. Hoeksema, C. A. Chen, P. O. Ang, H. Huang, D. J. W. Lane, S. T. Vo, Z. Waheed, Y. A. Affendi, T. Yeemin, and L. M. Chou, 2015: Extraordinary diversity of reef corals in the South China Sea. Mar. Biodivers., 45, 157-168, doi: 10.1007/s12526-014-0236-1. [Link]

Hubbard, D. K., 2011: Reef Drilling. In: Hopley, D. (Ed.), Encyclopedia of Modern Coral Reefs, Encyclopedia of Earth Sciences Series, Springer, Dordrecht, 856-869, doi: 10.1007/978-90-481-2639-2_54. [Link]

Hughes, T. P., M. L. Barnes, D. R. Bellwood, J. E. Cinner, G. S. Cumming, J. B. C. Jackson, J. Kleypas, I. A. van de Leemput, J. M. Lough, T. H. Morrison, S. R. Palumbi, E. H. van Nes, and Marten Scheffer, 2017: Coral reefs in the Anthropocene. Nature, 546, 82-90, doi: 10.1038/nature22901. [Link]

Inoue, S., H. Kayanne, N. Matta, W. S. Chen, and Y. Ikeda, 2011: Holocene uplifted coral reefs in Lanyu and Lutao Islands to the southeast of Taiwan. Coral Reefs, 30, 581-592, doi: 10.1007/s00338-011-0783-x. [Link]

Jones, R. S., R. H. Randall, Y.-M. Cheng, H. T. Kami, and S.-M. Mak, 1972: A marine biological survey of southern Taiwan with emphasis on corals and fishes. Insti- tute of Oceanography, National Taiwan University, Special Publication 1, 93 pp.

Keshavmurthy, S., C.-Y. Kuo, Y.-Y. Huang, R. CarballoBolaños, P.-J. Meng, J.-T. Wang, and C. A. Chen, 2019: Coral Reef Resilience in Taiwan: Lessons from Long-Term Ecological Research on the Coral Reefs of Kenting National Park (Taiwan). J. Mar. Sci. Eng., 7, 388, doi: 10.3390/jmse7110388. [Link]

Kuo, C.-Y., Y. S. Yuen, P.-J. Meng, P.-H. Ho, J.-T. Wang, P.-J. Liu, Y.-C. Chang, C.-F. Dai, T.-Y. Fan, H.-J. Lin, A. H. Baird, and C. A. Chen, 2012: Recurrent disturbances and the degradation of hard coral communities in Taiwan. PLoS One, 7, e44364, doi: 10.1371/journal. pone.0044364. [Link]

Lin, C.-H., 2010: Morphology of otolith of living and fossil fishes from Taiwan. Master Thesis, National Taiwan University, 207 pp. (in Chinese)

Lin, C.-H. and C.-W. Chien, 2022: Late Miocene otoliths from northern Taiwan: Insights into the rarely known Neogene coastal fish community of the subtropical northwest Pacific. Hist. Biol., 34, 361-382, doi: 10.1080/08912963.2021.1916012. [Link]

Lin, C.-H., C.-W. Chien, S.-W. Lee, and C.-W. Chang, 2021: Fish fossils of Taiwan: A review and prospection. Hist. Biol., 33, 1362-1372, doi: 10.1080/08912963.2019.1698563. [Link]

Löser, H. and W. Liao, 2001: Cretaceous corals from Tibet (China) - Stratigraphic and palaeobiogeographic aspects. J. Asian Earth Sci., 19, 661-667, doi: 10.1016/ S1367-9120(00)00063-8. [Link]

Ota, Y., J. B. H. Shyu, C.-C. Wang, H.-C. Lee, L.-H. Chung, and C.-C. Shen, 2015: Coral boulders along the coast of the Lanyu Island, offshore southeastern Taiwan, as potential paleotsunami records. J. Asian Earth Sci., 114, 588-600, doi: 10.1016/j.jseaes.2015.08.001. [Link]

Pandolfi, J. M., 2011: The paleoecology of coral reefs. In: Dubinsky, Z. and N. Stambler (Eds), Coral Reefs: An Ecosystem in Transition, Springer, Dordrecht, 13-24, doi: 10.1007/978-94-007-0114-4_2. [Link]

Pandolfi, J. M., S. R. Connolly, D. J. Marshall, and A. L. Cohen, 2011: Projecting coral reef futures under global warming and ocean acidification. Science, 333, 418422, doi: 10.1126/science.1204794. [Link]

Retallack, G. J., 2002: Carbon dioxide and climate over the past 300 Myr. Philos. Trans. R. Soc. Lond. Ser. A-Math. Phys. Eng. Sci., 360, 659-673, doi: 10.1098/ rsta.2001.0960. [Link]

Ribas-Deulofeu, L., V. Denis, S. De Palmas, C.-Y. Kuo, H. J. Hsieh, and C. A. Chen, 2016: Structure of benthic communities along the Taiwan latitudinal gradient. PLoS One, 11, e0160601, doi: 10.1371/journal. pone.0160601. [Link]

Ribas-Deulofeu, L., V. Denis, P.-A. Château, and C. A. Chen, 2021: Impacts of heat stress and storm events 
on the benthic communities of Kenting National Park (Taiwan). PeerJ, 9, e11744, doi: 10.7717/peerj.11744. [Link]

Riegl, B., A. Bruckner, S. L. Coles, P. Renaud, and R. E. Dodge, 2009: Coral reefs: Threats and conservation in an era of global change. Ann. N.Y. Acad. Sci., 1162, 136-186, doi: 10.1111/j.1749-6632.2009.04493.x. [Link]

Shen, C.-C., C.-C. Wu, C.-F. Dai, and S.-Y. Gong, 2018: Variable uplift rate through time: Holocene coral reef and neotectonics of Lutao, eastern Taiwan. J. Asian Earth Sci., 156, 201-206, doi: 10.1016/j. jseaes.2018.01.016. [Link]

Spalding, M., L. Burke, S. A. Wood, J. Ashpole, J. Hutchison, and P. zu Ermgassen, 2017: Mapping the Global Value and Distribution of Coral Reef Tourism. Mar. Pol., 82, 104-113, doi: 10.1016/j.marpol.2017.05.014. [Link]

Tsao, S., E. Hong, S.-R. Song, H.-T. Chu, and S.-H. Chung, 1992: The Absolute Age of the Boundary between Nanchuang and Kueichulin Formations. Spec. Publ. Cent. Geol. Surv., 6, 223-234. (in Chinese)

Turnšek, D., S. Buser, and I. Debeljak, 2003: Liassic Coral Patch Reef above the "Lithiotid Limestone" on
Trnovski Gozd Plateau, West Slovenia. Razprave IV. Razreda Sazu, 44, 285-331.

Van der Horst, C. J., 1922: The Madreporaria of the Siboga Expedition, Part III: Madreporaria Eupsammidae, Siboga-Expeditie, 16c, E.J. Brill, Leiden, 29 pp.

Wang, S.-W., 1997: Restrospective and prospect of coral reef research in Taiwan. Proceedings of the Symposium on the 5th Coral Reef Conference, 41-61. (in Chinese)

Wang, S.-W., S.-Y. Gong, H.-S. Mii, and C.-F. Dai, 2006: Cold-Seep Carbonate Hardgrounds as the Initial Substrata of Coral Reef Development in a Siliciclastic Paleoenvironment of Southwestern Taiwan. Terr. Atmos. Ocean. Sci., 17, 405-427, doi: 10.3319/ TAO.2006.17.2.405(TT). [Link]

Wells, J. W., 1954: Recent corals of Marshall Islands, Bikini and Nearby Atolls, Part 2, Oceanography (Biologic), Geological Survey Professional Paper 260-I, United States Government Printing Office, Washington, 385486. [Link]

Yamaguchi, M. and Y. Ota, 2004: Tectonic Interpretations of Holocene Marine Terraces, East Coast of Coastal Range, Taiwan. Quat. Int., 115-116, 71-81, doi: 10.1016/S1040-6182(03)00097-1. [Link] 